\title{
CORVITIN RESTORES METALLOTHIONEIN AND GLIAL FIBRILLARY ACIDIC PROTEIN LEVELS IN RAT BRAIN AFFECTED BY PITUITRIN-IZADRIN
}

\author{
H. N. SHIYNTUM ${ }^{1}$, O. O. DOVBAN 1 , Y. P. KOVALCHUK', \\ T. Ya. YAROSHENKOㄹ, G. A. USHAKOVA ${ }^{1}$ \\ ${ }^{1}$ Oles Honchar Dnipro National University, Ukraine; \\ ${ }^{2} I$. Horbachevsky Ternopil State Medical University, Ukraine; \\ e-mail:hnkafor@yahoo.com
}

\begin{abstract}
In this research, we investigated the effect of pituitrin-izadrin induced injury on the levels of metallothionein (MT) and soluble and filament forms of glial fibrillary acidic protein (GFAP) in the hippocampus, cerebellum, thalamus, and the cerebral cortex, and examined the effect of corvitin on the brain under the noted changes. Our results showed oppositely directed changes - a decrease in the level of $M T$ and an increase in GFAP in the rat brain, with a tendency to astrogliosis development, under the influence of systemic deficiencies in myocardial function. The use of corvitin at a dose of $42 \mathrm{mg} / \mathrm{kg}$ for five days after a cardiac attack caused by pituitary-izadrin leads to recovery in the balance of the studied proteins.
\end{abstract}

Key words: metallothionein, glial fibrillary acidic protein, pituitrin, izadrin, corvitin, brain.

A

strocytes are amongst the earliest and prominent to express changes under attacks [1]. They are the most numerous nonneuronal cell types in the central nervous system (CNS) and make up about $50 \%$ of the volume of the human brain $[1,2]$. Their functions are known to be critical, such as scavenge transmitters released during synaptic activity, control ion and water homeostasis, release neurotrophic factors, shuttle metabolite, and waste products, and to participate in the formation of the blood-brain-barrier [3, 4]. Failure of any of these supportive functions of astrocytes will constitute a threat to neuronal survival. Astrocytes are home to a number of essential proteins of the CNS, including metallothionein and glial fibrillary acidic protein, which presumably carry out some astrocyte functions.

Metallothioneins (MTs) are cysteine-rich, low molecular weight, heat stable proteins firstly described by Margoshes [5]. They are largely synthesized in the liver and the kidney in humans but are found at a number of other sites. In the CNS, MT-I and MT-II are conspicuously absent from neuronal populations, yet abundant in fibrous and protoplasmic astrocytes. MT is detectable in the extracellular fluid of the injured brain and astrocytes are capable of secreting MT in a regulatable manner [6].

MTs have been implicated as regulatory molecules in gene expression, homeostatic control of cellular metabolism of metals, and cellular adaptation to stress. Thus, they fulfill a regulatory capacity and influence transcription, replication, protein synthesis, metabolism, as well as other zinc-dependent biological processes [7]. It has been shown that the ability of animals to recover from CNS injuries or degenerative diseases depends on the deficiency or excess availability of MT-I/-II [7-11]. MT has equally been demonstrated to be down-regulated in cases of induced intoxication [12] and infection [13] but its correlated effect to other astrocyte proteins has yet to be tested.

GFAP is expressed in mature astrocytes in the CNS [14]. It is a member of the family of cytoskeletal proteins and is the primary intermediate filament with a size of 8-9 $\mathrm{nm}$, highly specific to the CNS. However, it has been found outside the CNS in relatively low amounts [15]. It has two physicochemical GFAP forms: water-soluble (sGFAP) and filament (fGFAP) [16]. The sGFAP is unevenly distributed in various brain regions, with the maximum con-

(C) 2017 Shiyntum H. N. et al. This is an open-access article distributed under the terms of the Creative Commons Attribution License, which permits unrestricted use, distribution, and reproduction in any medium, provided the original author and source are credited. 
tent in the medulla oblongata and the minimum in the cerebral cortex. In comparison with the cerebral cortex, an increased GFAP content in the hypothalamus and other structures may not only be due to an increase in the number of glial cells but also to a change in the ratio of fibrous and protoplasmic astrocytes [17]. GFAP plays a special role in the formation of astrocytic units, in response to stimulation by neurons, as well as in plastic rearrangement processes of synaptic connections [18]. Its expression is also required for the maintenance of white matter and blood-brain barrier integrity [19, 20], modulation of astrocytes and movement ensuring stable morphology of their processes in the development of reactive astrogliosis [21, 22]. In the event of an ischemic attack, a prominent ultrastructural change is the accumulation of intermediate glial filaments [23] consisting of GFAP and vimentin [2].

Changes in the supply of blood, oxygen, and glucose in mammals are caused by a series of factors, including stress, inflammation, and other damages, that can trigger the changes in astrosyte function [24]. The main objective of our study was the investigation of the corvitin effect on astrocytic proteins, MT and two forms of GFAP, in different areas of the rat brain affected by a pituitrin-izadrin related injury.

\section{Materials and Methods}

Eighteen Wistar rats, divided into three groups $(n=6)$, were used. Group 1 - control rats maintained under standard condition, group 2 - rats with the pituitrin-izadrin-induced effect, group 3 - rats with pituitrin-izadrin-induced effect + corvitin treatment under the scheme recommended by the manufacturer (PJSC SIC Borshchahivskiy CPP, Kyiv, Ukraine), for 5 days. The rats simulated the state of the combined administration of pituitrin and izadrin as elaborated below. They were placed under standard conditions with natural changing of lights and with compliance to general emergency diet. All the animals had free access to food and water. The experiment was performed according to the "Provisions for the use of animals in biomedical experiments" [25].

The pituitrin-izadrin experimental model. To develop the model for the induction of the injury effect, we used pituitrin (Endokrininiai, Lithuania) and $\beta$-agonists izadrin (isoprenaline hydrochloride, Sigma, USA). The administration of pituitrin and izadrin were performed as follows: intraperitoneal administration of $0.5 \mathrm{U} / \mathrm{kg}$ of pituitrin, followed by the subcutaneous introduction of $100 \mathrm{mg} / \mathrm{kg}$ izadrin after $20 \mathrm{~min}$, followed by another izadrin injection $6 \mathrm{~h}$ later, and $24 \mathrm{~h}$ later the administration of pituitrin and izadrin in the same doses as mentioned above. This model allegedly leads to disruption in cardiac systemic processes, responsible for the clinical course of acute coronary heart disease [26].

Treatment of the pituitrin-izadrin effect with corvitin. After induction of myocardial damages by the pituitrin-izadrin, the rats were treated with corvitin: $42 \mathrm{mg} / \mathrm{kg}$ b.w. was administered three times on the first day, twice on each of the next three days, and once on the fifth day at intervals of 2, 12 and $24 \mathrm{~h}$.

The open field test. The study of the physiological activity of the rats under experiment was conducted by means of the open field test according to Buresh [27]. This activity was tested in the middle of the day, at the beginning of the experiment under control, after the induction of damages by pituitrin and izadrin, and after treatment, using a white plastic box $(80 \times 80 \mathrm{~cm})$, divided by black lines into 16 squares $(20 \times 20 \mathrm{~cm})$ and placed $50 \mathrm{~cm}$ from the ground. 9 holes $(\mathrm{d}=4 \mathrm{~cm})$ were created at the intersection of the four internal squares. The rats under investigation were placed at the corner of the box and videos focusing on all the behaviors investigated were recorded for 3 minutes each. Testing was performed in the same phase of the light cycle. To avoid distractions, the field surface was treated with $70 \%$ ethanol solution after each animal test. The behavioral features determined included the number of lines crossed by the rats, vertical stands, hole-peeping, and defecation. This technique allows for simultaneous investigation of the locomotion, research activity, and autonomic-emotional state of animals.

Protein extraction and determination. At the end of the experiment, the rats were decapitated under anesthesia (thiopental, $60 \mu \mathrm{g} / \mathrm{kg}$ ). To investigate functional properties of the astrocytic proteins, namely MT and GFAP, under this model of the pituitrin-izadrin effect, the hippocampus, cerebellum, thalamus, and cerebral cortex were isolated and used to obtain soluble and fibrous cytoskeletal proteins by differential ultracentrifugation and protein solubilization in the presence of urea $(4.0 \mathrm{M})$ [24]. The extracting buffer contained $25 \mathrm{mM}$ Tris ( $\mathrm{pH} 7.4$ ), $1.0 \mathrm{mM}$ EDTA, $2.0 \mathrm{mM}$ dithiothreitol, $0.2 \mathrm{mM}$ phenylmethylsulfonyl fluoride (PMSF), $0.01 \%$ sodium nitride (NaN3), (indicated reagents were purchased from Sigma, USA). 
The MT content in the different brain areas was determined by the method of solid-phase enzyme-linked immunosorbent assay (ELISA), using monospecific polyclonal antibodies against the MT (Santa Cruz Biotechnology Inc., USA), purified MTstandard, and secondary antibodies against rabbit IgG conjugated to horseradish peroxidase (Sigma, USA). The content of GFAP in the obtained fractions was determined using monospecific polyclonal antibodies against GFAP (Santa Cruz Biotechnology Inc., USA), secondary antibodies against rabbit IgG conjugated to horseradish peroxidase (Sigma, USA), and pure GFAP (Boehringer Mannheim, Germany) as the corresponding purified protein-standard [28].

Results were measured using ELISA reader Anthos 2010 (Finland) at $492 \mathrm{~nm}$. The level of proteins was expressed in micrograms per $g$ of tissue.

The data are reported as means \pm SEM. Statistical analysis was performed by the unpaired twotailed Student's $t$-test and Pearson's correlation using "Microsoft $\AA$ Office Excel 2007" application packages, and one-way analysis of variance (ANOVA) using SPSS Statistics. Values with $P<0.05$ were considered statistically significant.

\section{Results and Discussion}

We observed the behavior of the experimental rats in an open field to determine how they were affected by the conditions under which they were subjected. Compared to the controlled animals, the rats under the influence of the induced pituitrin-izadrin attack were less lively, as their activity was significantly decreased when crossing lines in the open field, peeping into holes, and attempting vertical stands (Fig. 1). This is obviously due to the breakdown in metabolism caused by the insufficient provision of oxygen and glucose to tissues. During this period of difficulty caused by the induced attack, the rats randomly dropped feces around, whereas the rats under control were without feces. The reason for this could only be attributed to the inability of the mechanism responsible for this feature to function properly under the influence of the pituitrin-izadrin attack.

The pituitrin-izadrin induced myocardial injury caused a down-regulation in MT concentration in three of the four brain areas (hippocampus, thalamus, and cerebellum) tested as evidenced by the differences in values between the control and the induced attack (Fig. 2). Significant down-regulations between the control and the pituitrin-izadrin effects were only registered in the hippocampus (8.6 \pm 0.5 to $6.2 \pm 0.2 \mu \mathrm{g} / \mathrm{g}$ of tissue) and thalamus (7.3 \pm 0.2 to $6.1 \pm 0.3 \mu \mathrm{g} / \mathrm{g}$ of tissue). In the cerebral cortex, the level of MT was slightly up-regulated (4.8 \pm 0.1 to $5.1 \pm 0.15 \mu \mathrm{g} / \mathrm{g}$ of tissue).

Under the pituitrin-izadrin effect, there was a significant up-regulation in the sGFAP concentration in the cerebellum with respect to control; $64.7 \pm 1.8$ rising to $82.3 \pm 1.5 \mu \mathrm{g} / \mathrm{g}$ of tissue and in the cerebral cortex with respect to control; rising from $48.3 \pm 1.8$ to $68.2 \pm 3.6 \mu \mathrm{g} / \mathrm{g}$ of tissue, meanwhile, there was an insignificant increase in the hippocampus and a slight down-regulation in the thalamus (Fig. 3).

The results obtained indicate significant increases in the level of the filament form of GFAP under the pituitrin-izadrin effect in all investigated areas of the brain (Fig. 4). In the cerebellum, the concentration of fGFAP in the control group was registered at $379.7 \pm 14.7 \mu \mathrm{g} / \mathrm{g}$ tissue and increased under the influence of pituitrin-izadrin to $448.6 \pm 12.4 \mu \mathrm{g} / \mathrm{g}$ tissue, in the cerebral cortex - from $359.6 \pm 13.2 \mu \mathrm{g} / \mathrm{g}$ tissue to $406.2 \pm 7.9 \mu \mathrm{g} / \mathrm{g}$ tissue, in the thalamus from $313.5 \pm 8.2 \mu \mathrm{g} / \mathrm{g}$ tissue to $357.6 \pm 21.4 \mu \mathrm{g} / \mathrm{g}$ tissue, and in the hippocampus from $302.6 \pm 9.5 \mu \mathrm{g} / \mathrm{g}$ tissue to $373.7 \pm 14.3 \mu \mathrm{g} / \mathrm{g}$ tissue.

Pituitrin is an extract of bovine posterior pituitary hormones, oxytocin, and vasopressin [29] and izadrin is a medication used in the treatment of slow heart rate, heart block, and in rare situations, asthma [30]. Their combined effect causes decreased blood flow, limiting the supply of oxygen and glucose to tissues. Most of the consequences of the pituitrinizadrin-induced damages are initiated in the heart but subsequently, they could overwhelm the entire body. The development of cardiovascular diseases leads to the disruption of the heart and changes in blood flow, which lead to oxidative stress and the activation of inflammatory processes, not only in the heart muscle, but also indirectly reduces the supply of oxygen to the brain [24].

It has been earlier shown that the concentration of MT is generally down-regulated [11-13] and that of GFAP is up-regulated [2, 31, 32] under various harmful conditions, while under those same conditions, changes in vimentin and GFAP levels are simultaneous [2]. All of these are changes that occur under the processes of the major pathological role played by astrocytes in the brain and spinal cord [2]. Astrocytes are thought to exert a neuroprotective effect in stroke by shielding neurons from oxidative stress. This hypothesis is based on the ability of as- 


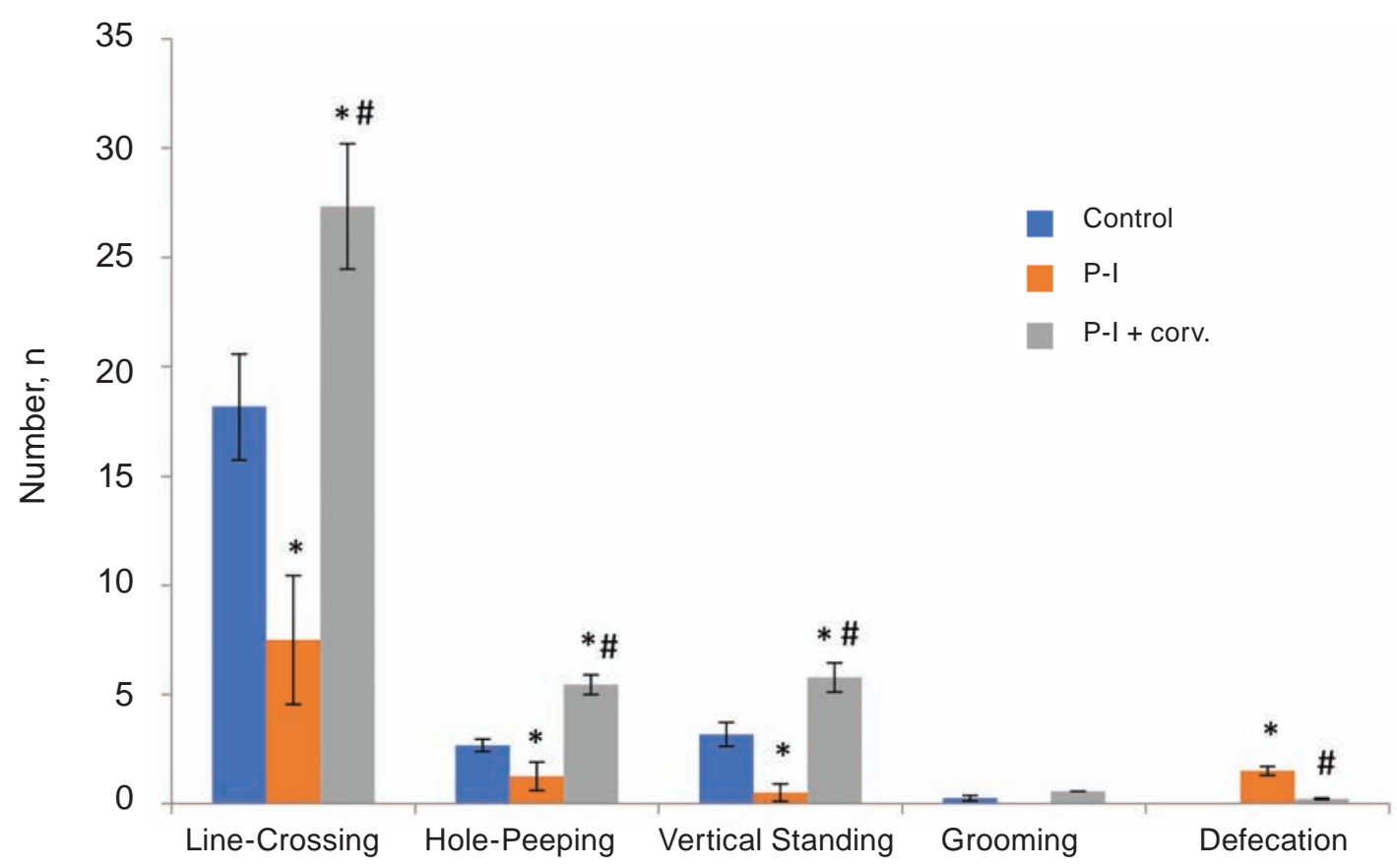

Fig. 1. Physiological activities of the rats in open field. Control-standard condition, P-I-Pituitrin-izadrininduced effect, and P-I + corv. - Pituitrin-izadrin-induced effect + corvitin treatment. * Significant changes with respect to control; \# significant changes with respect to the pituitrin-izadrin-induced effect

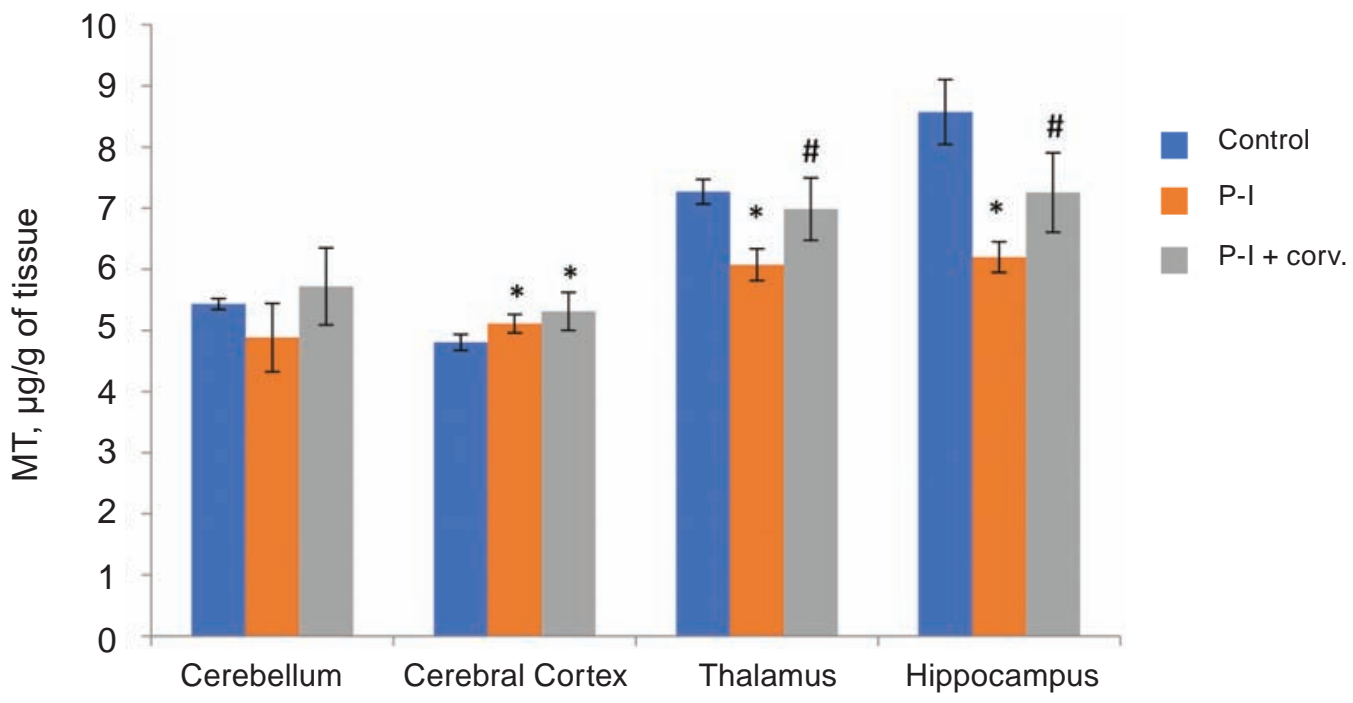

Fig. 2. The level of metallothionein in the rat brain. Here and in Fig. 3-4: Control-standard condition, P-IPituitrin-izadrin-induced effect, and P-I + corv - Pituitrin-izadrin-induced effect + treatment with corvitin. $* P<0.05$ with respect to control; $\# P<0.05$ with respect to the pituitrin-izadrin-induced effect; $n=6$

trocytes to engage in spatial buffering, to transport and metabolize amino acids, glucose, and other key molecules, and to up-regulate antioxidants and free radical scavengers in the injured region. Reactive astrocytes undergo changes in morphology and in their expression of a wide range of molecules while responding to CNS injury, including brain ischemia, mechanical trauma, neurodegenerative diseases, and tumors [2]. Following our experiment, it is quite probable that the induced pituitrin-izadrin impact induces astrogliosis, culminating in a decrease in MT concentration and an increase in the concentration of 


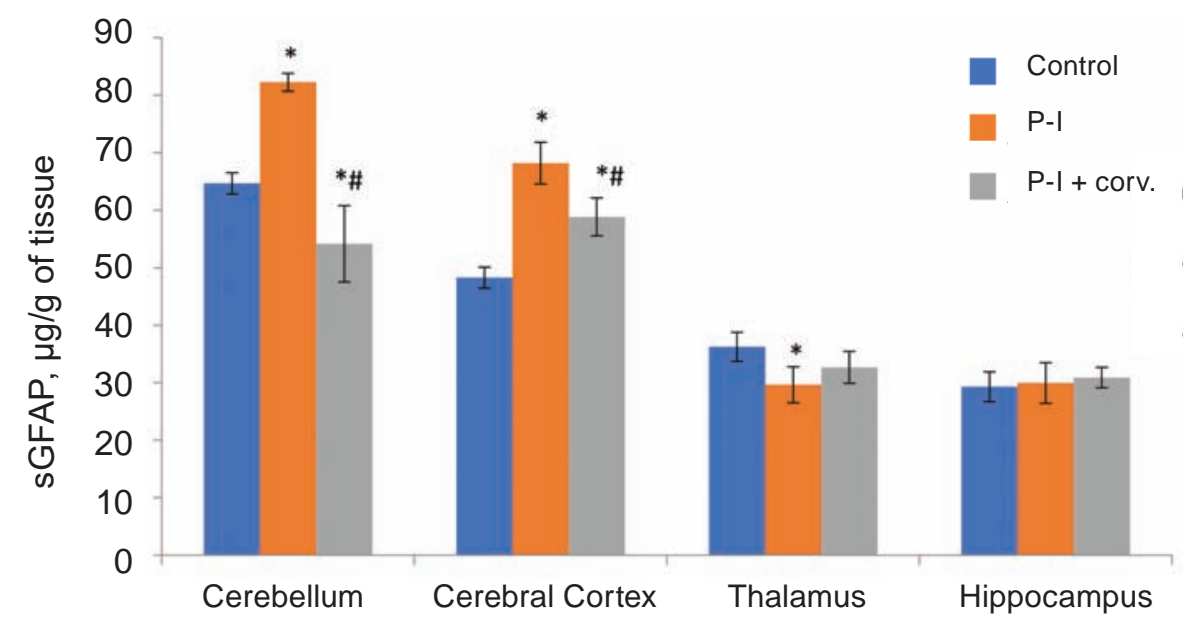

Fig. 3. The level of the soluble form of glial fibrillary acidic protein in the rat brain

sGFAP and fGFAP in the brain, in what appears to be a parallel action.

Given that the pituitrin-izadrin attack causes disruption in the proper systemic functioning of mechanisms in the heart, eventually leading to insufficient blood and oxygen supply, it is likely that its consequences are destructive, and similar in nature to another cardiac disorder, ischemia, that has been studied recently in the heart [3] and in the brain [33]. In both cases, significant amounts of oxygen free radicals (oxidants) are generated in the disruption, and oxidative stress plays an important role in brain damage [34]. As astrocyte proteins, MT is implicated as a scavenger of free radicals [12] during related oxidative damages, while GFAP is highly predictive in its quantitative measures [2]. This is so despite the evidence from the open field obser- vation that the system suffers during moments of low concentration of MT and high concentration of GFAP. This would explain why survival is maximal in MT- and GFAP-rich media [2, 7-11] and possibly why this induced attack causes the respective changes noted in these proteins. GFAP release mirrors injury to astrocytes located both in the white and gray matter and may increase owing to damage to glial cells [35]. Endogenous MT is thought to be actively secreted by astroglia and picked up by neurons through the low density lipoprotein receptorrelated protein 2 (LRP-2/megalin) and the LRP-1 receptor [36]. Megalin-mediated internalization of MT-II was shown in vitro, and megalin is mainly expressed in ependyma and neuronal cells. MTmediated activation of megalin receptor triggers intracellular activation of transcription factors, which

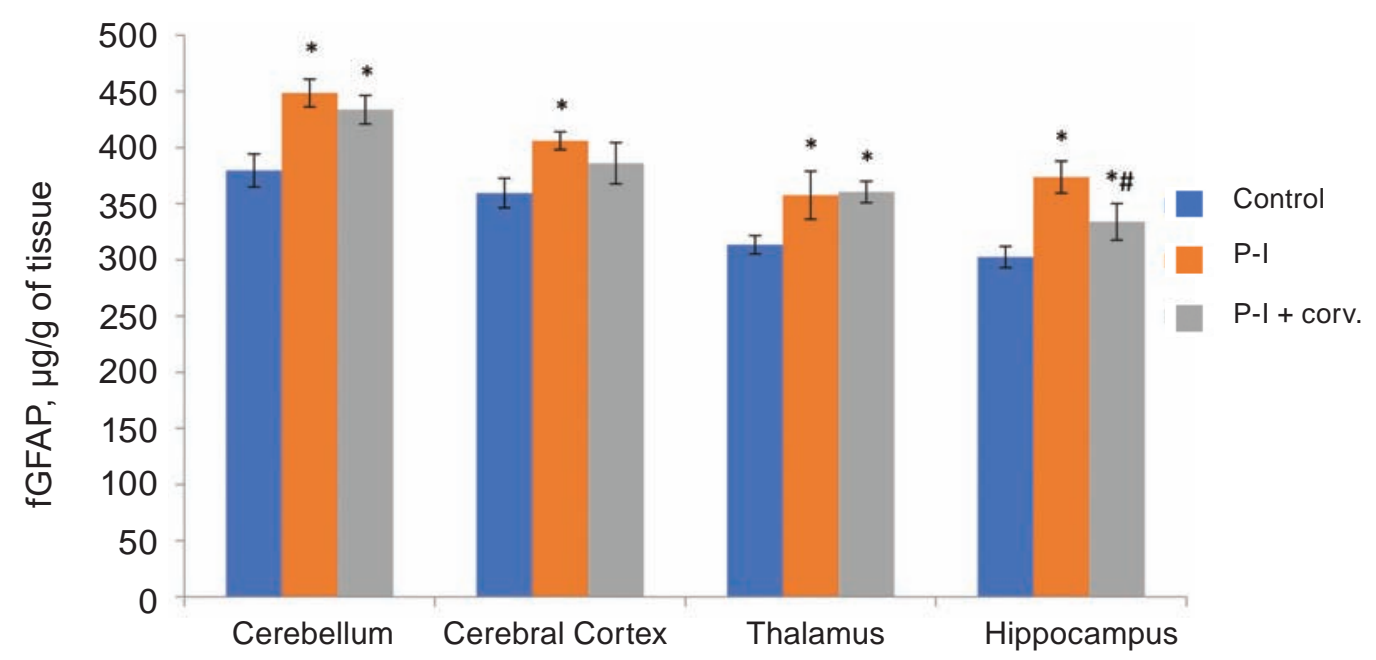

Fig. 4. The level of the filamentous form of glial fibrillary acidic protein in the rat brain 
involves the phosphoinositide 3-kinase pathway and the cAMP response element binding protein (CREP). The protective effects of MT are said to be mediated either via binding to membrane receptors from the low-density-lipoprotein (LDL)-family, especially by LDL receptor- 1 and -2 (megalin receptor) or by a direct metal- or reactive oxygen species-scavenging effect [36]. Reactive astrocytes have been proposed to represent a target for future therapeutic strategies to promote injury prevention, regeneration, and plasticity in the brain under injurious condition [33] and hypothetically, this suggestion should hold for the experimental myocardial injury.

The administration of corvitin had a positive impact on the rats in the open field. This was further highlighted by the fact that, when compared to the control, the activity rate under the corvitin effect was higher. There was a significant increase in the number of lines crossing, hole-peeping, and attempts at vertical standing. The rate at which the rats defecated also reduced. This implies that corvitin is useful in ameliorating the disruptive condition created by the induced pituitrin-izadrin effect.

In the experimental assay, the administration of corvitin not only reversed the course of the induced effect on the brain's MT concentration, it restored this content in the cerebellum and cerebral cortex to levels significantly higher than in their respective control groups by 5.3 and $10.6 \%$. The values recorded in the hippocampus and thalamus were 15 and $4 \%$ less than in the control respectively but all were significantly higher than in the pituitrin-izadrin-induced model by $12 \%$ in the hippocampus, $15 \%$ in the cerebellum, $13 \%$ in the thalamus and $4.2 \%$ in the cerebral cortex. With the administration of corvitin, the soluble form of cerebellar GFAP level decreased by $34-36 \%$ when compared to the induced pituitrinizadrin effect and approaching the initial rates seen in the control experiment. The treatment with corvitin, of the cerebellum, the cerebral cortex, and the thalamus, bore insignificant changes in fGFAP level, while in the hippocampus there was a significant down-regulation to $333.9 \pm 19.2 \mu \mathrm{g} / \mathrm{g}$ tissue, all with respect to the pituitrin-izadrin effect.

Corvitin (quercetin) belongs to a flavonoid which falls in a subgroup of flavonols. It shows angioprotective properties mediated by its effect on proteasomal proteolysis [37]. It can also be considered as a tool that amplifies gastric mucosal defense mechanisms without affecting the secretion of gastric hydrochloric acid and total protein [38].
The cardio-protective side of corvitin is expressed in its stimulation of the formation of nitric oxide in improving the metabolism of an ischemic site by reducing the size of the ischemic area. It also improves recovery processes after a stroke and heart attack, restoring blood circulation and microcirculation without marked changes of vascular tone. Corvitin possesses an antioxidant activity related to its ability to inhibit lipid peroxidation and eliminate free radicals.

According to results from the treatment of the pituitrin-izadrin effect with corvitin, it is safe to assume that the substance ensures the reinstatement of the functioning of the studied brain areas, by eliminating the free radicals released upon the induced effect of pituitrin and izadrin. This is evident in the restoration of the level of MT and GFAP (albeit not to completion in GFAP in most areas of the brain). Its antioxidant activity is hypothetically the reason why MT and GFAP levels recover upon its introduction, relieving them of their supposed scavenging and predictive functions. The restoration process further confirms the simultaneous changes in the content of all three proteins under different circumstances.

Apparently, MT and the soluble and filament forms of GFAP are related in their reaction to the pituitrin-izadrin effect. The Pearson's correlation coefficients obtained indicated a range of simultaneous links between these astrocyte proteins (Table). The down-regulation in MT concentration and the up-regulation in GFAPs' forms are opposite but coexisting outcomes of the pituitrin-izadrin induced effect. The existing relationship between these three proteins, although mostly weak, is parallel.

In the cerebellum, strong correlated changes are registered amongst all three proteins when the conditions of the induced pituitrin-izadrin effect and the corvitin effect are compared; the strength of the correlated changes being in the order sGFAP-fGFAP > sGFAP-MT > fGFAP-MT. In the other brain areas, the order of the correlated changes beginning with the strongest pair was: cerebral cortex - sGFAPfGFAP > fGFAP-MT > sGFAP-MT; thalamus fGFAP-MT > sGFAP-fGFAP > sGFAP-MT; and hippocampus - sGFAP-MT > sGFAP-fGFAP > fGFAP-MT. These changes indicate the functional impact of any given protein pair with respect to both conditions of investigation. In the cerebellum and the thalamus, the rate of function of the first two pairs seems to be of equal strength under the two studied 
Correlation links between MT, sGFAP, and fGFAP levels in the rat brain

\begin{tabular}{l|c|c|c|c|c|c|c|c}
\hline \multirow{2}{*}{ PCC, $\mathrm{r}$} & \multicolumn{2}{|c|}{ Cerebellum } & \multicolumn{2}{c|}{ Cerebral Cortex } & \multicolumn{2}{c|}{ Thalamus } & \multicolumn{2}{c}{ Hippocampus } \\
\cline { 2 - 9 } & P-I & $\begin{array}{c}\text { P-I }+ \\
\text { Corv. }\end{array}$ & P-I & $\begin{array}{c}\text { P-I }+ \\
\text { Corv. }\end{array}$ & P-I & $\begin{array}{c}\text { P-I }+ \\
\text { Corv. }\end{array}$ & P-I & $\begin{array}{c}\text { P-I + } \\
\text { Corv. }\end{array}$ \\
\hline sGFAP-fGFAP & -0.52 & 0.53 & 0.11 & 0.72 & $\mathbf{0 . 8 2}$ & 0.60 & 0.06 & 0.44 \\
sGFAP-MT & -0.42 & 0.33 & -0.22 & -0.34 & -0.37 & -0.27 & $\mathbf{0 . 8 2}$ & 0.23 \\
fGFAP-MT & -0.06 & $\mathbf{0 . 8 5}$ & $\mathbf{- 0 . 8 5}$ & -0.37 & $\mathbf{- 0 . 8 7}$ & 0.12 & 0.71 & 0.64 \\
\hline
\end{tabular}

Note. P-I - pituitrin-izadrin-induced effect, P-I + Corv. - pituitrin-izadrin-induced effect + corvitin effect, PCC Pearson's correlation coefficient, sGFAP-fGFAP - correlation between the soluble and filament forms of GFAP, sGFAPMT - correlation between the soluble form of GFAP and MT, fGFAP-MT - correlation between the filament form of GFAP and MT. Bold - significant correlation coefficient, $P<0.05$

conditions, meanwhile in the remaining cases, the rate of function seems to either diminish or increase moving from the pituitrin-izadrin induced injury to the corvitin effect.

If considered under just one of either given investigated conditions, the strength of the simultaneous functioning of any given protein pair in the cerebellum and thalamus is strongly noted in the pair sGFAP-fGFAP in both studied cases, while also evident in the fGFAP-MT pair under the corvitin effect in the cerebellum, and the fGFAP-MT pair under the pituitrin-izadrin effect in the thalamus. In the cerebral cortex, a strong relationship only exists between the sGFAP-fGFAP pair under the corvitin effect and the fGFAP-MT pair under the pituitrinizadrin effect, while in the hippocampus, it is noted between the sGFAP-MT and fGFAP-MT pairs under the pituitrin-izadrin effect, and the fGFAP-MT pair under the corvitin effect.

Our results show that the pituitrin-izadrin induced experimental injury is clearly responsible for the diminished changes observed in MT level and the increased contents of sGFAP and fGFAP in the rat brain depending on the area. The effect of corvitin administered in a dose of $42 \mathrm{mg} / \mathrm{kg}$ b.w. at different intervals, over a period of five days under injury led to restoration in the levels of all three studied proteins.

\section{КОРВІТИН ПОНОВЛЮЕ РІВЕНЬ МЕТАЛОТІОНЕЇНУ І ГЛІАЛЬНОГО ФІБРИЛ ЯРНОГО КИСЛОГО ПРОТЕЇНУ В МОЗКУ ЩУ РІВ В УМОВАХ ВПЛИВУ ПІТУ ̈̈ТРИН- ІЗАДРИНУ}

\author{
О. Н. Шийнтум ${ }^{1}$ О. О. Довбань ${ }^{1}$, \\ Ю. П. Ковальчук', Т. Я. Ярошенко ${ }^{2}$, \\ Г. О. Ушакова ${ }^{1}$
${ }^{1}$ Дніпровський національний університет імені Олеся Гончара, Україна;
${ }^{2}$ ДВНЗ «Тернопільський державний медичний університет імені
I. Я. Горбачевського МОЗ України»; e-mail: hnkafor@yahoo.com

\begin{abstract}
Досліджено вплив пітуїтрин-ізадрин індукованого пошкодження на вміст металотіонеїну (МТ), розчинної та філаментної форм гліального фібрилярного кислого протеїну (ГФКП) в гіпокампі, мозочку, таламусі й корі головного мозку щурів, спричиненого системним ефектом пітуїтрину та ізадрину, а також вплив корвітину на мозок за зазначених пошкоджень. Одержані результати показали протилежно спрямовані зміни у мозку щурів: зниження рівня МТ і підвищення ГФКП з тенденцією до розвитку астрогліозу під впливом системних ушкод-
\end{abstract}


жень функції міокарда. Застосування корвітину в дозі 42 мг/кг протягом п'яти днів після серцевої атаки, спричиненої пітуїтрин-ізадрином, призводить до відновлення балансу досліджуваних протеїнів.

К л ю ч в в с с о в а: металотіонеїн, гліальний фібрилярний кислий протеїн, пітуїтрин, ізадрин, корвітин, мозок.

\section{КОРВИТИН ВОЗОБНОВЛЯЕТ УРОВЕНЬ МЕТАЛЛОТИОНЕИНА И ГЛИАЛЬНОГО ФИБРИЛЛЯРНОГО КИСЛОГО ПРОТЕИНА В МОЗГЕ КРЫС ПОСЛЕ ВОЗДЕЙСТВИЯ ПИТУИТРИНА-ИЗАДРИНА}

\author{
O. Н. Шийнтум ${ }^{1}$, Е. А. Довбань', \\ Ю. П. Ковальчук', Т. Я. Ярошенко ${ }^{2}$, \\ Г. А. Ушакова ${ }^{1}$ \\ ${ }^{1}$ Днепровский национальный университет \\ имени Олеся Гончара, Украина; \\ ${ }^{2}$ ГВУЗ «Тернопольский государственный \\ медицинский университет имени \\ И. Я. Горбачевского МЗ Украины»; \\ e-mail: hnkafor@yahoo.com
}

Исследовано влияние питуитрин-изадрин индуцированного нарушения на содержание металлотионеина (МТ), растворимой и филаментной форм глиального фибриллярного кислого протеина (ГФКП) в гиппокампе, мозжечке, таламусе и коре головного мозга крыс, вызванного системным эффектом питуитрина и изадрина, а также влияние корвитина на мозг при указанных воздействиях. Полученные результаты показали противоположно направленные изменения в мозге крыс: снижение уровня МТ и повышение ГФКП с тенденцией развития астроглиоза при влиянии системных недостатков функции миокарда. Применение корвитина в дозе 42 мг/кг в течение пяти дней после сердечной атаки, вызванной питуитрин-изадрином, приводит к восстановлению баланса исследуемых протеинов.

К л ю ч е в ы е сл о в а: металлотионеин, глиальный фибриллярный кислый протеин, питуитрин, изадрин, корвитин, мозг.

\section{References}

1. Molofsky AV, Krencik R, Ullian EM, Tsai HH, Deneen B, Richardson WD, Barres BA, Rowitch DH. Astrocytes and disease: a neurodevelopmental perspective. Genes Dev. 2012; 26(9): 891-907.

2. Li L, Lundkvist A, Andersson D, Wilhelmsson U, Nagai N, Pardo AC, Nodin C, Ståhlberg A, Aprico K, Larsson K, Yabe T, Moons L, Fotheringham A, Davies I, Carmeliet P, Schwartz JP, Pekna M, Kubista M, Blomstrand F, Maragakis N, Nilsson M, Pekny M. Protective role of reactive astrocytes in brain ischemia. J Cereb Blood Flow Metab. 2008; 28(3): 468-481.

3. Kalogeris T, Baines CP, Krenz M, Korthuis RJ. Cell biology of ischemia/reperfusion injury. Int Rev Cell Mol Biol. 2012; 298: 229-317.

4. Nedergaard M, Dirnagl U. Role of glial cells in cerebral ischemia. Glia. 2005; 50(4): 281-286.

5. Margoshes M, Vallee BL. A cadmium protein from equine kidney cortex. J Am Chem Soc. 1957; 79(17): 4813-4814.

6. Liu Z, Chopp M. Astrocytes, therapeutic targets for neuroprotection and neurorestoration in ischemic stroke. Prog Neurobiol. 2016; 144: 103120.

7. Briner W. The Alchemist's approach to metal poisoning: transforming the metal burden. Toxics. 2014; 2(3): 364-376.

8. Lynes MA, Hidalgo J, Manso Y, Devisscher L, Laukens D, Lawrence DA. Metallothionein and stress combine to affect multiple organ systems. Cell Stress Chaperones. 2014; 19(5): 605-611.

9. Penkowa M, Espejo C, Martínez-Cáceres EM, Poulsen CB, Montalban X, Hidalgo J. Altered inflammatory response and increased neurodegeneration in metallothionein $\mathrm{I}+\mathrm{II}$ deficient mice during experimental autoimmune encephalomyelitis. J Neuroimmunol. 2001; 119(2): 248-260.

10. Cai X, Wang J, Huang X, Fu W, Xia W, Zou M, Wang Y, Wang $\mathrm{J}$, Xu D. Identification and characterization of MT-1X as a novel FHL3binding partner. PLoS One. 2014; 9(4): e93723. . 
11. Chung RS, Penkowa M, Dittmann J, King CE, Bartlett C, Asmussen JW, Hidalgo J, Carrasco J, Leung YK, Walker AK, Fung SJ, Dunlop SA, Fitzgerald M, Beazley LD, Chuah MI, Vickers JC, West AK. Redefining the role of metallothionein within the injured brain: extracellular metallothioneins play an important role in the astrocyte-neuron response to injury. J Biol Chem. 2008; 283(22): 15349-15358.

12. Shiyntum HN, Ushakova GA. Protective. detoxicative function of metallothionein in the rat brain and blood induced by controlled cadmium doses. Visn Dnipropetr Univ Ser Biol Med. 2015; 6(2): 103-107.

13. Eidizadeh A, Khajehalichalehshtari M, Freyer D, Trendelenburg G. Assessment of the Therapeutic Potential of Metallothionein-II Application in Focal Cerebral Ischemia In Vitro and In Vivo. PLoS One. 2015; 10(12): e0144035.

14. Surjawan Y, As'ad S, Ranakusuma TAS, Wijaya A. The different pattern of S100b protein and GFAP concentrations in ischemic stroke. Med J Indonesia. 2013; 22(4): 215-220.

15. Middeldorp J, Hol EM. GFAP in health and disease. Prog Neurobiol. 2011; 93(3): 421-443.

16. Kovalenko TM, Osadchenko IO, Tsupykov OM, Pivneva TA, Shalamai AS, Moibenko OO, Skybo HH. Neuroprotective effect of quercetin during experimental brain ischemia. Fiziol $\mathrm{Zh}$. 2006; 52(5): 21-27. (In Ukrainian).

17. Pócsai K, Kálmán M. Glial and perivascular structures in the subfornical organ: distinguishing the shell and core. $J$ Histochem Cytochem. 2015; 63(5): 367-383.

18. Ikeshima-Kataoka H. Neuroimmunological Implications of AQP4 in Astrocytes. Int $J$ Mol Sci. 2016; 17(8). pii: E1306.

19. Lu H, Cassis LA, Kooi CW, Daugherty A. Structure and functions of angiotensinogen. Hypertens Res. 2016; 39(7): 492-500. .

20. Brenner M. Role of GFAP in CNS injuries. Neurosci Lett. 2014; 565: 7-13.

21. Kimura $\mathrm{T}$, Kambe $\mathrm{T}$. The Functions of Metallothionein and ZIP and ZnT Transporters: An Overview and Perspective. Int J Mol Sci. 2016; 17(3): 336.

22. West AK, Hidalgo J, Eddins D, Levin ED, Aschner M. Metallothionein in the central nervous system: Roles in protection, regeneration and cognition. Neurotoxicology. 2008; 29(3): 489-503.
23. Takano T, Oberheim N, Cotrina ML, Nedergaard M. Astrocytes and ischemic injury. Stroke. 2009; 40(3 Suppl): S8-S12.

24. Fomenko OZ, Ushakova GO, Pierzynowski SG. Proteins of astroglia in the rat brain under experimental chronic hepatitis and 2-oxoglutarate effect. Ukr Biokhim Zhurn. 2011; 83(1): 69-76. (In Ukrainian).

25. Medical ethics and human rights: the provisions for the use of animals in biomedical experiments. Exp Clin Physiol Biochem. 2003; 22(2): 108-109. (In Ukrainian).

26. Belenichev IF, Kucherenko LI, Volchik YuA, Abramov AV, Bukhtiyarova NV. Some aspects of cardioprotective activity of new $\beta$-adrenoblocker with NO-mimetic effect "Hypertril" on myocardial infarction model. Pharmacol Drug Toxycol. 2014; 40(4-5): 11-16. (In Russian).

27. Buresh R, Berg K, French J. The effect of resistive exercise rest interval on hormonal response, strength, and hypertrophy with training. J Strength Cond Res. 2009; 23(1): 62-71.

28. Ngo TT, Lenhoff GM, Yaklich A. ELISA. Moscow: Mir. 1998; P. 444 (In Russian).

29. Hooper KC, Jrssup DC. The distribution of enzymes destroying oxytocin and vasopressin in human placentae. J Physiol. 1959; 146(3): 539549.

30. Kleinau G, Pratzka J, Nürnberg D, Grüters A, Führer-Sakel D, Krude H, Köhrle J, Schöneberg T, Biebermann H. Differential modulation of Beta-adrenergic receptor signaling by trace amine-associated receptor 1 agonists. PLoS One. 2011; 6(10): e27073.

31. Huang L, Wu ZB, Zhuge Q, Zheng W, Shao B, Wang B, Sun F, Jin K. Glial scar formation occurs in the human brain after ischemic stroke. Int J Med Sci. 2014; 11(4): 344-348.

32. Kovalchuk YP, Prischepa IV, Si U, Nedzvetsky VS, Kot YG, Persky EE, Ushakova GA. Distribution of glial fibrillary acidic protein in different parts of the rat brain under cadmium exposure. Ukr Biochem J. 2015; 87(3): 116-123.

33. Kovalenko TN, Ushakova GA, Osadchenko I, Skibo GG, Pierzynowski SG. The neuroprotective effect of 2-oxoglutarate in the experimental ischemia of hippocampus. J Physiol Pharmacol. 2011; 62(2): 239-246.

34. Chen H, Yoshioka H, Kim GS, Jung JE, Okami N, Sakata H, Maier CM, Narasimhan P, 
Goeders CE, Chan PH. Oxidative stress in ischemic brain damage: mechanisms of cell death and potential molecular targets for neuroprotection. Antioxid Redox Signal. 2011; 14(8): 1505-1517.

35. Brouns R, De Vil B, Cras P, De Surgeloose D, Mariën P, De Deyn PP. Neurobiochemical markers of brain damage in cerebrospinal fluid of acute ischemic stroke patients. Clin Chem. 2010; 56(3): 451-458.

36. West AK, Leung JY, Chung RS. Neuroprotection and regeneration by extracellular metallothionein via lipoprotein-receptor-related proteins. J Biol Inorg Chem. 2011; 16(7): 11151122.
37. Pashevin DO, Dosenko BIe, Byts' IuV, Moibenko OO. Antiatherogenic characteristics of korvitin: effect on proteasome activity of the aorta, heart, and blood cells. Fiziol Zh. 2009; 55(4): 50-57. (In Ukrainian).

38. Vovkun TV, Ianchuk PI, Shtanova LIa, Vesel'skyi SP, Baranovs'kyi VA. The influence of corvitin on secretory processes and blood flow in the rat gastric mucosa. Fiziol Zh. 2013; 59(1): 40-46. (In Ukrainian).

Received 07.03.2017 